\title{
Long-term assessment of a modified tibial tuberosity advancement technique in dogs
}

[Avaliação em longo prazo da técnica de avanço da tuberosidade tibial modificada em cães]

\author{
R.M. Medeiros ${ }^{1}$, M.A.M. Silva ${ }^{2}$, P.P.M. Teixeira ${ }^{3}$, D.G. Chung ${ }^{1}$, M.E.B.A.M. Conceição ${ }^{1}$, \\ G.O. Chierice ${ }^{4}$, J.G. Padilha Filho ${ }^{1}$, L.G.G.G. Dias ${ }^{1 *}$ \\ ${ }^{1}$ Universidade Estadual Paulista "Julio de Mesquita Filho" - Jaboticabal, SP \\ ${ }^{2}$ Universidade Federal de Goiás - Goiania, GO \\ ${ }^{3}$ Universidade Federal do Pará - Castanhal, PA \\ ${ }^{4}$ Universidade de São Paulo - São Paulo, SP
}

\begin{abstract}
The purpose of study was to assess long-term clinical and radiographic aspects of dogs' stifle joints which had undergone a modified tibial tuberosity advancement technique (mTTA). A total of 15 stifles that had undergone mTTA for CCL disease of 11 patients were included in this study. Assessments involved patient's gait analysis, cranial drawer and tibial compression tests, stifle goniometry range of articular motion, thigh and leg girth and radiographic evidence of progression of osteoarthrosis. Variables were compared between operated and healthy limbs and among moments (M0) on the early postop; (M1) 120 days postop; and (M2) approximately 5 years following surgery. A questionnaire regarding owner's perceptions after approximately 5 years of surgery was assessed. Most dogs presented positive response to cranial drawer and tibial compression tests on operated knees. There was also decrease on goniometry and thigh girth and increase in leg girth. Radiographic evidence of progression of osteoarthritis was seen especially on the long-term follow-up (M2). On gait analysis, most animals presented some degree of lameness in different conditions, in contrast to owners' perceptions. Osteoarthritis still develops in dogs following mTTA surgery for CCL disease. However, owners were overall satisfied with their recovery and would be willing to accept indication of mTTA for dogs with ruptured CCL.
\end{abstract}

Keywords: cranial cruciate ligament disease, stifle, laminess

\section{RESUMO}

O objetivo deste estudo foi avaliar, em longo prazo, aspectos clínicos e radiográficos do joelho de cães submetidos à técnica modificada de avanço da tuberosidade da tíbia (mTTA). Um total de 15 joelhos de 11 pacientes foram submetidos à mTTA para correção de doença do ligamento cruzado cranial. A avaliação envolvia análise de marcha do paciente, teste de compressão tibial e de gaveta, goniometria do joelho para amplitude articular, circunferência das pernas e coxas e evidência radiográfica de progressão da osteoartrose. As variáveis foram comparadas entre membros operados e saudáveis e entre os momentos (M0) no pósoperatório imediato; (M1) 120 dias de pós-operatório; e (M2) aproximadamente cinco anos após a cirurgia. Foi avaliado um questionário sobre as percepções do proprietário após aproximadamente cinco anos de cirurgia. A maioria dos cães apresentou resposta positiva aos testes de gavetas e de compressão tibial em joelhos operados. Houve também diminuição na goniometria e na circunferência da coxa e aumento do perímetro das pernas. Evidências radiográficas de progressão da osteoartrite foram observadas especialmente no seguimento de longo prazo (M2). Na análise de marcha, a maioria dos animais apresentou algum grau de claudicação em diferentes condições, em contraste com as percepções dos proprietários. A osteoartrite ainda se desenvolve em cães após a cirurgia de mTTA para doença CCL. No entanto, os proprietários estavam, em geral, satisfeitos com a recuperação dos animais e estavam dispostos a aceitar a indicação de mTTA para cães com doença do ligamento cruzado cranial.

Palavras-chave: ligamento cruzado cranial, joelho, claudicação

Recebido em 28 de novembro de 2016

Aceito em 26 de setembro de 2017

*Autor para correspondência (corresponding author)

E-mail: gustavogosuen@fcav.unesp.br 


\section{INTRODUCTION}

Cranial cruciate ligament (CCL) disease is one of the main causes of lameness of pelvic limbs in dogs. Several surgical techinques were developed to treat that condition (Muzzi et al., 2009; Griffon, 2010). Articular stabilization by neutralization of forces should be the main effort on surgery in cases of ruptured CCL, rather than ligament substitution or functional restoring techniques (Apelt et al., 2007; Kuhn et al., 2011). To restore stability of the stiffle joint is the principle of osteotomy techniques, such as tibial tuberosity advancement (TTA).

TTA has shown promising results compared to other surgical techniques (McDonald et al., 2013), which quickly gained popularity worldwide. Many modiffications regarding implant types and technical aspects have been proposed in order to improve results and become the technique more accessible (Etchepareborde et al., 2011; Samoy et al., 2014; Medeiros et al., 2016). A modified TTA technique (mTTA), using a wege-shaped cage manufactured of castor beans (Ricinus communis) polyurethane resin was proposed, with promissing results (Medeiros et al., 2016). Ricinus polyurethane resin presented excellent osseousbiocompactibility, especially by osteoconduction, in other orthopedic conditions (Kim et al., 2008; Regonato et al., 2009; Medeiros et al., 2016).

Long-term follow-up studies on patients following surgical repair of ruptured CCL are sparse and conflicting. Most surveys were based on clinical issues and questionnaire responded to by animal owners (Christopher et al., 2013; Molsa et al., 2013). Imaging techniques are critical to rule out progression of stiffle joint osteoarthrosis.

The purpose of this study was to perform longterm clinical and radiographic follow-up, as well as owners' perceptions on dogs undergone mTTA surgery for CCL disease.

\section{MATERIAL AND METHODS}

This study was approoved by the Ethics Committee with protocol number 016090/14. Fifteen stifle joints of 11 dogs (5 males and 6 females) submitted to mTTA for CCL disease were assessed for approximately five years (4.61 \pm 0.21 , range 4,33-5,1 years) postoperatively. Surveys included age, breed, gender, body score (range 1 to 9 ) and side of affected knee. All animals took part of a previous development feasibility study on the mTTA technique, involving 42 knees of 35 dogs bearing CCL disease (Medeiros et al., 2016). Most patients of that study were not included in this assessment due to death, unavailability of owners or unanswered contact.

Animals undergone examination on static standing position and gait analysis. Gait was ranked from 0 to 6 , according to severity of lameness as follows: 0, no lameness and no change on weight bearing noted; 1 , no lameness, presence of contralateral shift on weight bearing; 2 , lameness on pacing; 3 , lameness on trotting; 4 , lameness on both pacing and trotting; 5, do not support the affected limb wile trotting; 6, do not support the affected limb at anytime (Stein e Schmoekel, 2008; Bennett et al., 2013).

Assessments were carried out by three experienced orthopedic surgeons, blinded on previous information regarding history data and surgical treatment. Physical examinations included cranial drawer and tibial compression tests (Schulz, 2007). Comparison of affected and healthy stiffle joints was possible in 7 out of 11 dogs that included this study. The others had undergone bilateral surgery and, thus, were excluded from this comparison.

Operated stifles had undergone mediolateral and craniocaudal radiographic surveys. Radiographic images were evaluated in three moments: (M0) immediate postoperative; (M1) 120 days postop; and (M2), approximately 5 years postop. Signs of osteoarthrosis search included: presence of osteophytes at the proximal and distal rims of the patella, fabellas, at the caudal aspect of the tibial plateau and at the CCL insertion site; subcondral sclerosis of trochlear fossa, tibial plateau and/or fossa of the long extensor digital muscle; and presence of articular effusion. Those changes were ranked as absent (0), mild (1), moderate (2) or severe (3). Furthermore, the polimery implant was assessed about bone healing, in both areas, just proximal and distal to the implant, ostheointagration and ostheophytes formation. Radiographic images were assessed isolatedly for each of those changes, according to 
methodology used in previous trial (bennett et al., 2013). Radiographic assessments were carried out by three experienced radiologists, blinded on timepoint and patient.

Maximum flexion and extension angles of the stiffles joints (operated and healthy) were measured using goniometry, with the animals positioned in lateral recumbency.

Thigh and leg girth (perimetry) of the treated and healthy limbs (7 dogs with unilateral disease/surgery out of 11 studied) were measured according with previous study (Jaegger et al., 2002) using a tape graduated in centimeters, at the midpoint between the major trochanter and the femoral lateral condyle, and immediately below the end of the tibial crest. The results were converted in percentile, considering the circumference of the healthy limb as $100 \%$. This conversion aimed to minimize difference on particular physical characteristics of patients.

Owners received a questionaire regarding patient's long-term recovery following mTTA. Answer options were "yes" or "no" for issues as follows: lameness during pacing, trotting, following mild or hard exercises, when wake up and in cold days, lameness on any other moment; weight bearing on the operated limb; and pain. Owners responded about willingness to submit their dogs to the same surgical technique for treating CCL disease. Owners also rated the quality of recovery following surgery (excelent, good, regular or poor) and the need for analgesics/NSAIDs (never, rarely, usualy or always), according to their perceptions.

Data were displayed as mean ( \pm SD). All data were previously evaluated using KolmogorovSmirnov normality test. Gait and radiographic scores were not normally distributed. Thus, moments (M0, M1 and M2) were compaired using Friedman's test, followed by Dunn's posthoc test for multiple pairwise comparison.

Thigh and leg girth and stifle joint goniometry data presented normal distribution. Therefore, comparison between treated and healthy limbs was carried out using the $t$-test. Data from owner's questionnaire ("yes/no" answers) were distributed in contigency table and their frequencies were compaired between treated and healthy limb using Fisher's exact test.
Significance level adopted for all tests was 5\%. Statistical analysis was performed using computer software GraphPad Prism $4^{\text {TM }}$ (Prism 4.00 - GraphPad Software ${ }^{\mathrm{TM}}$ ).

\section{RESULTS}

Seven (63.64\%) out of 11 dogs included in this study belonged to large breed. Mean weight was $25.9 \pm 2.6 \mathrm{~kg}$ (range $5.4-41.0 \mathrm{~kg}$ ). Age ranged from six to 19 years (mean $9.73 \pm 4.0$ years). Mean body score was $5.27 \pm 1.90$ (range $3-9$ ). Modified TTA was carried out on nine right (60\%) and six left $(40 \%)$ stifle joints, totalizing 15 stifles treated for CCL disease.

Gait analysis revealed six patients scored 0 (40\%), one $(6,67 \%)$ escored 1 , two $(13,33 \%)$ escored 2, three (20\%) escored 3 and three (20\%) escored 4. No animal scored 5 or 6.

On physical examination, there was a difference between operated and heathy stifles. Cranial drawer test was positive on 13 (86.67\%) stifle joits. Tibial compression test was positive in all operated stifle joits. Among non-operated stifles, only one (14.28\%) knee was positive for tibial compression test, while none was positive on cranial drawer test. No patient experienced pain during clinical evaluation.

Regarding radiographic assessment, at M1 12 of out 15 knees showed complete bone healing in proximal and distal areas, showing no implant rejection. There was evident impair of most parameters indicating osteoarthrosis (Figure 1), except for articular efusion, which was absent. Differences $(\mathrm{P}<0.05)$ were clearer between imediate postop (M0) and long-term follow-up radiographies (M2). Moreover, all variables were significantly different between M0 and M2. Variables compared between M0 and M1 (120 days postop) did not differ significantly $(\mathrm{P}>0.05)$. For most parameters there was no significant difference between $\mathrm{M} 1$ and $\mathrm{M} 2$ (Table 1). There were screw fractures in three (20\%) out of 15 stifles operated. Those fractures were already noted at 120 days postop. Implants had been surgically removed in three patients (20\%) due to recurrent draining fistula. Microbiological tests were carried out, which evidenced absence of contamination or infection in those cases. 


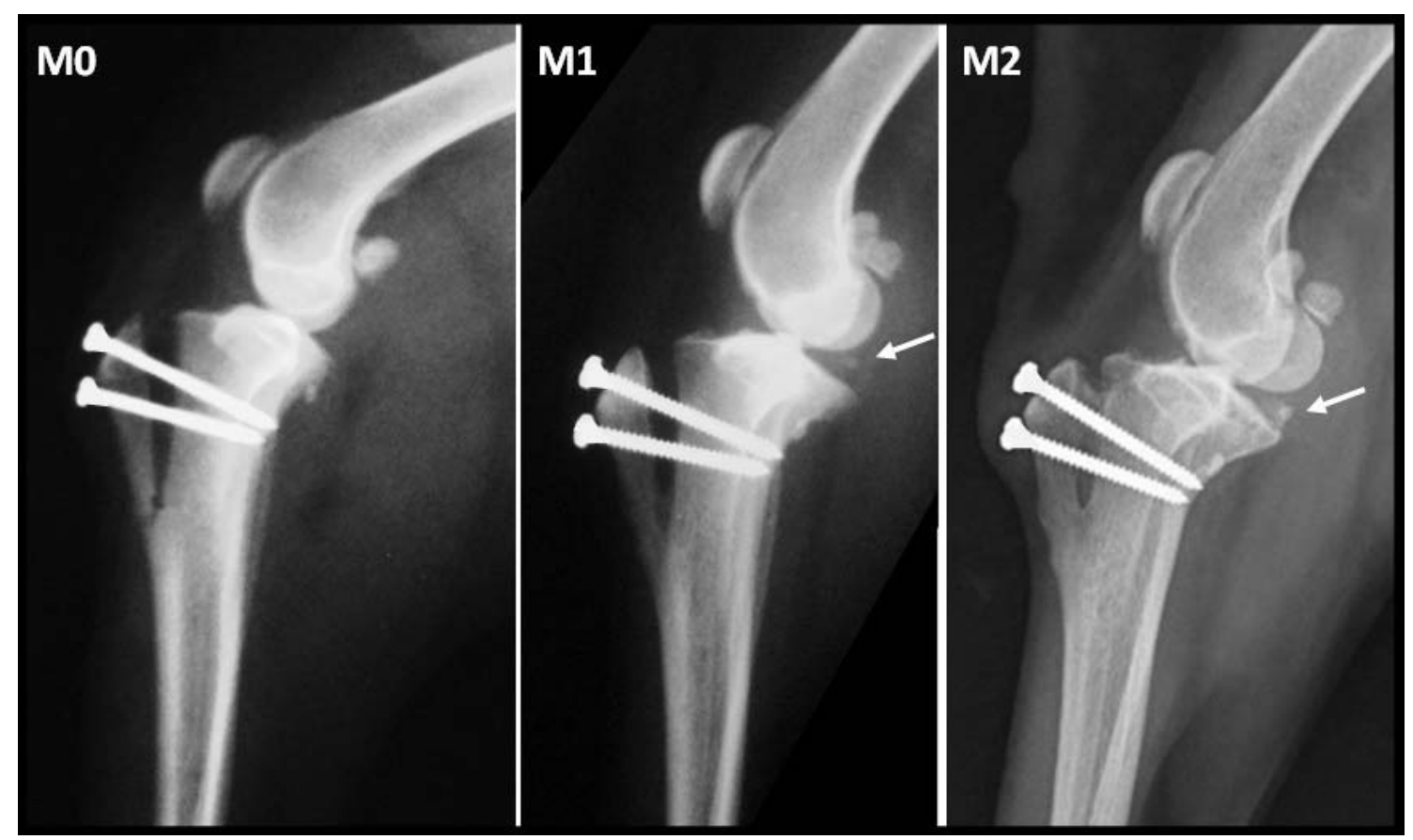

Figure 1. Radiographic images (medio-lateral projection) about stifle of a dog, who was performed modificated TTA techinique in different moments: imidiatilly postop (M0); 120 days postop (M1); 5 years postop (M2). It was observed Osteophytes caudal to the tibial plateau (arrow).

Mean goniometry at hyperetension of stifle of operated and non-operated stifles were $139.90^{\circ}$ $\left( \pm 18.12^{\circ}\right)$ and $142.10^{\circ}\left( \pm 12.20^{\circ}\right)$, respectively. Thigh girth on operated limb was $97.80 \%$ $( \pm 3.39 \%)$ of that measure on control (healthy) limb, while leg girth was $102.30 \%( \pm 7.87 \%)$.
Both goniometry and perimetry differed significantly between operated and healthy stifles $(P<0.05)$. There was reduction on both range of articular motion and thigh girth and increase on leg girth.

Table 1. Comparison of scores of radiographic changes in stifle joints of dogs undergone a modified TTA technique for CCL disease, ranked at immediate postop, 120 days (M1) and approximately 5 years (M2) postop

\begin{tabular}{lccc}
\multicolumn{1}{c}{ Parameters } & M0 & M1 & M2 \\
\hline Osteophytes on proximal/distal patellar rim & $0.53 \pm 0.56 \mathrm{a}$ & $0.84 \pm 0.43 \mathrm{ab}$ & $1.38 \pm 0.55 \mathrm{~b}$ \\
Osteophytes on the fabellas & $0.24 \pm 0.43 \mathrm{a}$ & $0.49 \pm 0.47 \mathrm{a}$ & $0.84 \pm 0.52 \mathrm{~b}$ \\
Osteophytes caudal to the tibial plateau & $0.64 \pm 0.34 \mathrm{a}$ & $0.80 \pm 0.37 \mathrm{a}$ & $1.64 \pm 0.48 \mathrm{~b}$ \\
Osteophytes on the tibial insertion of the CCL & $0.00 \pm 0.00 \mathrm{a}$ & $0.20 \pm 0.41 \mathrm{a}$ & $0.47 \pm 0.74 \mathrm{~b}$ \\
Subchondral sclerosis of trochlear fossa & $0.42 \pm 0.51 \mathrm{a}$ & $0.75 \pm 0.37 \mathrm{ab}$ & $1.00 \pm 0.56 \mathrm{~b}$ \\
Subchondral sclerosis of tibial plateau & $1.02 \pm 0.34 \mathrm{a}$ & $1.29 \pm 0.28 \mathrm{ab}$ & $1.44 \pm 0.50 \mathrm{~b}$ \\
Subchondral sclerosis of the LDEM fossa & $0.62 \pm 0.28 \mathrm{a}$ & $0.80 \pm 0.35 \mathrm{ab}$ & $1.09 \pm 0.40 \mathrm{~b}$ \\
Articular effusion & $1.04 \pm 0.53 \mathrm{a}$ & $0.87 \pm 0.45 \mathrm{ab}$ & $0.44 \pm 0.41 \mathrm{~b}$ \\
Overall assessment (sum of all scores per limb) & $4.89 \pm 2.29 \mathrm{a}$ & $6.69 \pm 1.50 \mathrm{a}$ & $9.27 \pm 2.37 \mathrm{~b}$ \\
\hline
\end{tabular}

Corresponding letters means no difference $(\mathrm{P}>0.05)$.

Frequency of owners reporting lameness on different conditions was one (6.67\%) on pacing, one $(6.67 \%)$ on trotting, one $(6.67 \%)$ following mild exercises, two (13.33\%), after heavy excercises, six (40\%) on wakening, four (26.67\%) during gold days. 
Owners rated long-term recovery as excellent in 14 out of 15 surgeries (93.33\%), one (6.67\%) rated as good and none classified it as regular or poor. Concerning frequency of need for analgesics or NSAIDs, owners responded "none" in 13 out of 15 surgeries (86.67\%) and "rarely" in two surgeries (13.33\%). All owners (100\%) would be willing to submit their dogs to mTTA for CCL rupture repair, according to the questionnaire.

\section{DISCUSSION}

Radiographic imaging revealed long-term progression of osteoarthrosis-related changes, except for articular efusion. Up to 120 days postop, there was no difference on any of the radiographic parameters in comparison to early postop images. These results were in contrast with findings of another study on TPLO surgery for CCL disease (Deluke et al., 2012). There were other reports concerning progression of degenerative articular disease in dogs bearing CCL rupture following surgery, regardless of surgical technique (Tatarunas and Matera, 2005) Articular efusion was present up to 120 days postop following extracapsular stabilization using fascia lata flap (Selmi et al., 2007), as also shown in this study. Moreover, both extracapsular repair using fascia lata (Buquera et al., 2007) and intracapsular stabilization using alogen graft fixed with interference screws (Oliveira et al., 2013) resulted in articular efusion for up to 360 days postop.

Some short-term complications were found in our study, like loosening of a screw, which was removed because of contamination. This kind of complication was shown in another study (Medeiros et al., 2016).

In our study there was evidence of osteoarthrosis progression on a long-term basis, although gait analysis revealed normal or minimally affected limb function, as proved by others (Gordon et al., 2003). Results on gait analysis contrasted with those related to owners' perceptions. Lack of experience and absence of clinical background may justify underestimation of mild lameness by owners, as found in other studies. Lameness is usually apparent for owners only in moderate or severe cases (Burton et al., 2009; Christopher et al., 2013).
Results on gait analysis differed slightly from those reported following TPLO (Moeller et al., 2010). The authors found lameness between 1-5 years postop in $14 \%$ of patients. However, those numbers may be underrated, as some patients were followed-up for a shorter period.

Lameness could also be related to meniscal injury in patients of this study. Meniscus tears are a relatively common condition in dogs bearing ruptured CCL, which leads to long-term degenerative changes (Christopher et al., 2013). However, meniscal injury was not ruled out in the current trial.

Most operated stifle joints were positive on cranial drawer and tibial compression tests, while non-operated joints presented negative results, as seen in another study (Might et al., 2013). Tibial compression test may be more sensitive than cranial drawer test (Schulz, 2007). In fact, this technique seems to be easier to perform in larger breed dogs, due to their muscular tension. Longterm articular instability doesn't seem to differ among techniques that mimetize CCL (Oliveira et al., 2013).

Operated stifles presented lower range of articular motion, as well as reduced thigh girth and increased leg girth. Those results were similar to the findings following TPLO (Moeller et al., 2010). It could be explained because all techniques to treat CCL deseases are imprecise and can loosen by the time, and allow little movement at long-term. In the same way, dogs undergone lateral extracapsular stabilization using suture have regained thigh muscle mass in nine weeks (Hoelzler et al., 2004). Other study reported progressive thigh atrophy in dogs following fascia lata extracapsular stabilization (Buquera et al., 2007).

The reason for increase in leg girth was not investigated in this study. However, it might be due to fibrosis adjacent to the osteotomy site. The technique provides cranial projection of the tibial crest. Another possible reason is muscle hypertrophy due to changes on stifle biomechanics. Nonetheless, further investigation is warranted in order to confirm such hypothesis.

In a surgury involving dogs submitted to TPLO, TTA or Tight Rope technique, $44-61 \%$ of owners detected signs of pain in their dogs one year 
postop, regardless of surgical tchnique (Christopher et al., 2013). Such results differed dramatically from those found in this study, as owners did not report any behavior of pain.

In this trial, $93.33 \%$ of owners rated recovery of their dogs as excellent, which was closely similar to results following traditional TTA technique (Hoffman et al., 2006). Moreover, all owners cited in the current investigation would be willing to submit their dog or other dogs to the same treatment option for ruptured CCL.

Medial motion of tibial tuberosity may predispose to medial patelar luxation following original TTA surgery (Hoffman et al., 2006). Patellar luxation has not occur so far in dogs that underwent modified TTA. We hypothesize that screws inserted towards craniocaudal direction avoid instability on the osteotomy site. However, it requires a larger number of dogs submitted to that technique and a longer period of follow-up in order to confirm such hypothesis.

In conclusion, dogs presented physical rehabilitation on the early postop and improved life quality approximately 5 years folowing mTTA surgery for ruptured CCL. Owners were absolutely satisfied about surgery results. Stifle joint osteoarthrosis progression should be expected. Most animals should present clinically detectable lameness on a long-term basis, it happens because of progressive ostheoartrosis.

\section{REFERENCES}

APELT, D.; KOWALESKI, M.P.; BOUDRIEAU, R.J. Effect of tibial tuberosity advancement on cranial tibial subluxation in canine cranial cruciate-deficient stifle joints: an in vitro experimental study. Vet. Surg., v.36, p.170-177, 2007.

BENNETT, D.; ECKERSALL, P.D.; WATERSTON, M. et al. The effect of robenacoxib on the concentration of C-reactive protein in synovial fluid from dogs with osteoarthritis. BMC Vet. Res., v.9, p.1-11, 2013.

BUQUERA, L.E.C.; PADILHA FILHO, J.G.; CANOLA, J.C. et al. Estabilização extraarticular do joelho com fáscia lata autógena em cães de raças de grande porte. Arq. Bras. Med. Vet. Zootec., v.59, p.685-694, 2007.
BURTON, N.J.; OWEN, M.R.; COLBORNE, G.B.; TOSCANO, M.J. Can owners and clinicians assess outcome in dogs with fragmented medial coronoid process? Vet. Comp. Orthop. Traum., v.22, p.183-189, 2009.

CHRISTOPHER, S.A.; BEETEM, J.; COOK, J.L. Comparison of -teromg outcomes associated with three surgical techniques for treatment of cranial cruciate ligament disease in dogs. Vet. Surg., v.42, p.329-334, 2013.

DELUKE, A.M.; ALLEN, D.A.; WILSON, E.R. et al. Comparison of radiographic osteoarthritis scores in dogs less than 24 months or greater than 24 months following tibial plateau leveling osteotomy. Can. Vet. J., v.53, p.1095-1099, 2012.

ETCHEPAREBORDE, S.; BRUNEL, L.; BOLLEN, G.; BALLIGAND, M. Preliminary experience of a modified Maquet technique for repair of cranial cruciate ligament rupture in dogs. Vet. Comp. Orthop. Traum., v.24, p.223227, 2011.

GORDON, W.J.; CONZEMIUS, M.G.; RIEDESEL, E. et al. The relationship between limb function and radiographic osteoarthritis in dogs with stifle osteoarthritis. Vet. Surg., v.32, p.451-454, 2003.

GRIFFON, D.J. A review of the pathogenesis of canine cranial cruciate ligament disease as a Basis for future preventive strategies. Vet. Surg., v.39, p.399-409, 2010.

HOELZLER, M.G.; MILLIS, D.L.; FRANCIS, D.A.; WEIGEL, J.P. Results of arthroscopic versus open arthrotomy for surgical management of cranial cruciate ligament deficiency in dogs. Vet. Surg., v.33, p.146-153, 2004.

HOFFMANN, D.E.; MILLER, J.M.; LANZ, O.I. et al. Tibial tuberosity advancement in 65 canine stifles Vet. Comp. Orthop. Traum., v.19, p.219227, 2006.

JAEGGER, G.; MARCELLIN-LITTLE, D.J.; LEVINE, D. Reability of goniometry in Labrador Retrievers. Am. J. Vet. Res., v.63, p.979-986, 2002.

KIM, S.E.; POZZI, A.; KOWALESKI, M.P.; LEWIS D.D. Tibial osteotomies for cranial cruciate ligament insufficiency in dogs. Vet. Surg., v.37, p.111-125, 2008. 
KÜHN, K.; OHLERTH, S.; MAKARA, M. et al. Radiographic and ultrasonographic evaluation of the patellar ligament following tibial tuberosity advancement. Vet. Rad. Ultrasound, v.52, p.466471, 2011.

MACDONALD, T.L.; ALLEN, D.A.; MONTEITH, G.J. Clinical assessment following tibial tuberosity advancement in 28 stifles at 6 months and 1 year after surgery. Can. Vet. J., v.54, p.249-254, 2013.

MEDEIROS, R.M.; SILVA, M.A.M.; TEIXEIRA, P.P.M. et al. Use of castor bean polymer in developing a new technique for tibial tuberosity advancement for cranial cruciate ligament rupture correction in dogs. Vet. Med., v.61, p.382-388, 2016.

MIGHT, K.R.; BACHELEZ, A.; MARTINEZ, S.A.; GAY, J.M. Evaluation of the drawer test and the tibial compression test for differentiating between cranial and caudal stifle subluxation associated with cruciate ligament instability. Vet. Surg., v.42, p.392-397, 2013.

MOELLER, E.M.; ALLEN, D.A.; WILSON, E.R. et al. Long-term outcomes of thigh circumference, stifle range-of-motion, and lameness after unilateral tibial plateau leveling osteotomy. Vet. Comp. Orthop. Traum., v.1, p.37-42, 2010.

MOLSA, S.H.; HIELM-BJÖRKMAN, A.K.; LAITINEN-VAPAAVUORI, O.M. Use of an owner questionnaire to evaluate long-term surgical outcome and chronic pain after cranial cruciate ligament repair in dogs: 253 cases (2004-2006). J. Am. Vet. Med. Assoc., v.243, p.689-695, 2013.

MUZZI, L.A.L.; REZENDE, C.M.F.; MUZZI, R.A.L. Fisioterapia após substituição artroscópica do ligamento cruzado cranial em cães. I - Avaliação clínica, radiográfica e ultrassonográfica. Arq. Bras. Med. Vet. Zootec., v.61, p.805-814, 2009.
OLIVEIRA, G.G.S.; PADILHA FILHO, J.G.; CANOLA, J.C. Evaluation of glycerin conserved patellar ligament allograft, secured with interference screws as a substitute of the cranial cruciate ligament in dogs. Vet. Surg., v.42, p.5656, 2013.

REGONATO, E.; CANOLA, J.C.; CHIERICE, G.O.; PADILHA FILHO, J.G. Avaliação radiográfica da cobertura acetabular à cabeça femoral, após osteotomia tripla e aplicação de cunha sacroilíaca, em pelve de cadáveres de cães. Pesqui. Vet. Bras., v.29, p.625-631, 2009.

SAMOY, Y.; VERHOEVEN, G.; BOSMANS, T. et al. TTA Rapid: description of the technique and short term clinical trial results of the first 50 cases. Vet. Surg., v.43, p.1-11, 2014.

SCHULZ, K. Cranial cruciate ligament rupture. In: FOSSUM, T.W. Manual of small animal surgery. 3.ed. [Philadelphia]: Elsevier, 2007. p.1254-1275.

SELMI, A.L.; PADILHA FILHO, J.G.; LINS, B.T.; MENDES, G.M.; EIMANTAS, G.C. Incisuroplastia troclear e estabilização articular após transecção do ligamento cruzado cranial. Estudo clínico e radiográfico em cães. Ciênc. Rural, v.37, p.1360-1366, 2007.

STEIN, S.; SCHMOEKEL, H. Short-term and eight to 12 months results of a tibial tuberosity advancement as treatment of canine cranial cruciate ligament damage. J. Small Anim. Prac., v.49, p.398-404, 2008.

TATARUNAS, A.C.; MATERA. J.M. Tratamento da ruptura do ligamento cruzado cranial no cão. Rev. Educ. Cont. CRMV. v.8, p.26-37, 2005. 